\title{
かん詰食品への抗生物質の利用
}

\author{
第 2 報 ナイシンの微生物学的定量法
}

(昭 和 42 年 9 月 16 日 受理)

$\begin{array}{lllll}\text { 田 中 昭 二* } & \text { 小野 輝 昭* } \\ \text { 松田 典 彦* 宮 井 久 } & \end{array}$

\section{Application of Antibiotics to Canned Food}

II. Microbiological Assay of Nisin

Shoji TANAKA, Teruaki ONO, Norihiko MATSUDA and Hisako MIYAI

(Laboratory of the Canners Association of Japan: 460 Kariba-cho, Hodogaya-ku, Yokohama)

A vertical diffusion method for quantitative analysis of Nisin in canned food was discussed. Bacillus stearothermophilus IAM 1035 was used as test organisms for this study. Results obtained may be summarized as follows:

1. Dispense $9 \mathrm{ml}$ of nutrient agar (meat extract $0.5 \%$, Polypeptone $1.0 \%, \mathrm{NaCl} 0.5 \%$, Agar-agar $1.5 \%, \mathrm{pH} 7.0$ ) in sterile $16 \mathrm{~mm} \times 160 \mathrm{~mm}$ cotton-stoppered tubes. Sterilize in an autoclave for 15 minutes at $121^{\circ} \mathrm{C}$.

2. Spore suspensions of $B$. stearothermophilus are prepared in nutrient agar slants with incubation at $55^{\circ} \mathrm{C}$ for five to seven days until 80 per cent or more cells are in the spore state. Spores are suspended in sterile saline to give the desired concentration $\left(6 \times 10^{6}\right.$ $\sim 6 \times 10^{5} / \mathrm{ml}$ ), and heat-shocked for 10 minutes at $80^{\circ} \mathrm{C}$ before putting them into the test media.

3. An one ml portion of spore suspension is added to the test media which have been melted in water bath. After thoroughly mixing, the media are dispensed in sterile $5 \mathrm{~mm}$ $\times 75 \mathrm{~mm}$ cotton-stoppered tubes and solidified at vertical position in cold water.

4. The sample adjusted to $\mathrm{pH} 6.0$ was stratified on the agar media and stored for 120 minutes at $30^{\circ} \mathrm{C}$.

5. After incubation for 18 hours at $55^{\circ} \mathrm{C}$, the length of inhibited zone is measured through a projector $(\times 20)$ and read at the level of $0.01 \mathrm{~mm}$. The concentration of Nisin is obtained from the standard curve.

(Received September 16, 1967)

日常に桝る抗生物質の定量法としては，実用的な立 昜からみると感度がよく, 回収率が高くかつ誤差のすく ない方法であると同時に分析手段としての簡便さが要求 される.ナイシン (Nisin) の定量法に関しては従来ペー ヘークロマトグラフ法1), レサズリン法2), その他希积拡 敀法年4)などが提唱されているが，それぞれ一長一短があ り目的に応じて使い分けられなければならない，本実験 こ扰いてはかん詰食品からの回収を目的とした定量法と

* 社団法人 日本缶詰協会研究所：横浜市保土ヶ谷区 狩場町 460
して Bacillus stearothermophilus を用いた垂直拡散 法（重層法）について，その測定条件の検討を行なった のでここに報告する.

実験および結果

[予備実験］検定菌と定量法の選択

まず検定菌を選択するために, 当研究所保存菌株中 Clostridium 属10株, Bacillus 属30株について胞子の 発芽能力やナイシン感受性について検討したところ胞子 の発芽率がよく，またナイシンに対して敏感に反応する Bacillus stearothermophilus IAM 1035 を検定菌として 
採用した.なお, 検定菌としてのB. stearothermophilus の利点は, 本菌胞子が $80 \sim 100^{\circ}$ 程度の熱処理ではほと んど影響されず, 発育適温が $55^{\circ}$ 付近にあるところから 操作中に混入した雑菌によるスポイルを防止できること にある.

つぎに，定量法を選定するために本菌株を用いて円筒 平板法, 口紙平板法ならびに重層法について比較試験を 行なった結果, 操作が簡便で, 検定用培地や試料が少量 ですみ，感度が良好な重層法をナイシンの定量法として 採用することにした。

重層法の測定要領はつぎのごとくである.

1. あらかじめ検定用寒天培地を $9 \mathrm{ml}$ ずつ中試験管に 分注し, $121^{\circ}, 15$ 分間高压隇菌しておく.

2. 湘定に当たってこの培地を水浴で溶かし，これに隇 菌生理食塩水に眯濁させた検定菌胞子液 $1 \mathrm{ml}$ を加え， 十分靦找したのち $5 \phi \times 75 \mathrm{~mm}$ の隇菌小訌験管に分注 し, 冷水中で垂直状態に固化させる.

3.この㠜固した検定用寒天培地上に試料を重層し, 一 定時間放置したのち $55^{\circ}, 18 \sim 24$ 時間培養し，その阻 止帯の長さを透影機で20倍に拡大し, $0.01 \mathrm{~mm}$ の点ま で測定する。

\section{[実験 1] 検定用培地の寒天湿度の検討}

条 件

基礎培地：普通ブイヨン（肉エキス $0.5 \%$ ，ペプトン $1.0 \%$ ，食塩 $0.5 \%, \mathrm{pH} 7.0$ )

寒天濃度: $1.0,1.25,1.5,1.75,2.0 \%$

胞子濃度: $2.3 \times 10^{6} / \mathrm{ml}$

ナイシン液: $100 \mathrm{u} / \mathrm{ml}$ のナイシンを含む Sörensen リ

ン酸緩衝液 $(\mathrm{pH} \mathrm{6.0)}$.

結 果

一元配置法による变量分析の結果, 寒天濃度の違いが

第 1-a 表 検定用培地中の寒天濃度が阻止帯の長さに及 ぼす影響

\begin{tabular}{|c|c|c|c|c|}
\hline 1.00 & 1.25 & 1.50 & 1.75 & 2.00 \\
\hline $595^{*}$ & 582 & 651 & 589 & 514 \\
\hline 638 & 698 & 620 & 538 & 571 \\
\hline 601 & 620 & 626 & 566 & 591 \\
\hline 674 & 603 & 612 & 591 & 566 \\
\hline 592 & 619 & 657 & 562 & 542 \\
\hline 731 & 677 & 588 & 605 & 490 \\
\hline 724 & 643 & 606 & 608 & 590 \\
\hline 690 & 685 & 597 & 652 & 633 \\
\hline 699 & 568 & 635 & 610 & 610 \\
\hline 687 & 620 & 653 & 636 & 605 \\
\hline
\end{tabular}

* 単位は $1 / 100 \mathrm{~mm}$, 同一試料につき 12 個の測定值を 得, 最大值と最小值は唅て, 10 個の測定値をとった.
第 1-b 表 寒天濃度の変量分析結果

\begin{tabular}{|c|c|c|c|c|}
\hline 因 & 変 動 & 自 由 度 & 不偏分散 & 分散 比 \\
\hline 寒天嘙度 & 49428.4 & 4 & 12357.1 & $7.287 * *$ \\
\hline 差 & 76301.6 & 45 & 1695.6 & \\
\hline 全 & 125730.0 & 49 & \multicolumn{2}{|c|}{$F_{45}^{4}=\frac{2.58 \cdots *}{3.77 \cdots * *}$} \\
\hline
\end{tabular}

第 1-c 表 寒天湌度間の有意差の検定

\begin{tabular}{c|c|c|c|c} 
寒天浱度 & $2.00 \%$ & $1.75 \%$ & $1.50 \%$ & $1.25 \%$ \\
\hline $1.00 \%$ & $* *$ & $* *$ & - & - \\
\hline $1.25 \%$ & $*$ & - & - & \\
\hline $1.50 \%$ & $*$ & - & & \\
\hline $1.75 \%$ & - & &
\end{tabular}

*危険率 $5 \%$ で有意差があると認められるもの

**危険率 $1 \%$ で有意差があると認められるもの

一有意差が認められないもの

阻止带の長さに影響していることがわかった（第 1-a， 1-b 表). そこで各濃度間の有意差を検定したところ第1c 表に示すように $1.75 \%$ と $1.0 \%, 2.0 \%$ と $1.5 \%, 1.25$ $\% ， 1.0 \%$ の間に有意差が認められた。

以上の結果から検定用培地の寒天濃度としては影響を 及ぼさない濃度範囲として1.5\%を採用することとした。

\section{[実験 2] 胞子漕度の検討}

条 件

胞子の形成: B. stearothermophilus IAM 1035 を保 存斜面から普通ブイョン（肉エキス $0.5 \%$, ポリペプト ソ $1.0 \%$, 食塩 $0.5 \%, \mathrm{pH} 7.0$ ) に植え継ぎ, $100^{\circ}, 2$ 3 分加熱急冷後 $55^{\circ}$ で18時間培養した新鮮培養液を胞子 形成寒天培地 $\left(0.05 \%\right.$ グルコースと $30 \mathrm{ppm} \mathrm{MnSO} 4 \cdot \mathrm{H}_{2} \mathrm{O}$ を含む pH 7.0 の普通寒天斜面）に移し， $55^{\circ} ， 7$ 日間培 盖した。

胞子濃度： $6.0 \times 10^{6}, 3.0 \times 10^{6}, 1.2 \times 10^{6}, 6.0 \times 10^{5}$ / $\mathrm{ml}$ (隇菌生理食塩水に懸濁)

ナイシン液： $10 \mathrm{u} / \mathrm{ml}$ のナイシンを含む $\mathrm{pH} 6.0$ の Sörensen リン酸緩衝液.

結 果

一元配置法による変量分析の結果 $6 \times 10^{6} \sim 6 \times 10^{5} / \mathrm{ml}$ の濃度範囲では $10 \mathrm{u} / \mathrm{ml}$ 濃度のナイシンの定量値に影響 が認められなかった（第 2-a, 2-b 表).

\section{[実験 3] 被検液の pH の検討}

条 件

被検液： $100 \mathrm{u} / \mathrm{ml}$ のナイシンを含む $\mathrm{pH} \mathrm{5.0,5.5，}$ $6.0,7.0$ の Sörensen リン酸緩衝液

胞子濃度: $2.4 \times 10^{6} / \mathrm{ml}$ 
第 2-a 表 検定用胞子照濁液の胞子灌度が阻止帯の長さ に及ぼす影響

\begin{tabular}{l|c|c:c}
\multicolumn{3}{c|}{ 胞子瀑度（個/ml） } \\
$6.0 \times 10^{6}$ & $3.0 \times 10^{6}$ & $1.2 \times 10^{6}$ & $6.0 \times 10^{5}$ \\
\hline $639 *$ & 636 & 632 & 648 \\
619 & 638 & 618 & 634 \\
644 & 616 & 648 & 635 \\
616 & 628 & 642 & 636 \\
611 & 627 & 636 & 619 \\
619 & 621 & 621 & 638 \\
629 & 638 & 630 & 621 \\
622 & 634 & 623 & 629 \\
627 & 611 & 625 & 630 \\
638 & 627 & 619 & 627
\end{tabular}

* 単位は $1 / 100 \mathrm{~mm}$

第 2-b 表 胞子濃度の変量分析結果

\begin{tabular}{|c|c|c|c|c|}
\hline 因 & 変 & 自 由 度 & 不偏分散 & 分 散 比 \\
\hline 胞子浱度 & 174.6 & 3 & 58.2 & \multirow[t]{2}{*}{0.60} \\
\hline 差 & 3491.8 & 36 & 97.0 & \\
\hline 全 体 & 3666.4 & 39 & \multicolumn{2}{|c|}{$F_{36}^{3}={ }_{4.38 \cdots * *}^{2.86 \cdots *}$} \\
\hline
\end{tabular}

第 3-a表 ナイシン被検液の $\mathrm{pH}$ が阻止帯の長さに 及ぼす影響

\begin{tabular}{l|l|l|l}
\multicolumn{3}{|c|}{$\mathrm{pH}$} \\
5.0 & 5.5 & 6.0 & 7.0 \\
\hline $722 *$ & 675 & 708 & 633 \\
711 & 666 & 702 & 666 \\
749 & 669 & 666 & 679 \\
723 & 694 & 709 & 670 \\
308 & 685 & 649 & 684 \\
772 & 697 & 666 & 665 \\
724 & 668 & 662 & 675 \\
730 & 684 & 680 & 656 \\
721 & 696 & 655 & 663 \\
722 & 710 & 649 & 656 \\
* 単位は & &
\end{tabular}

\section{結 果}

一元配置法に上る要因分析の結果 $\mathrm{pH}$ 5.0 7.0 の範囲 で $\mathrm{pH}$ 值の相違が阻止帯の長さに影響していることがわ ろった. そこで $\mathrm{pH}$ 値間の差を検定したところ， 5.5， j.0，7.0の間に有意差が認められた。なお， $\mathrm{pH} 5.0$ の 昜合 $\mathrm{pH}$ 值そのものの影響と思われるが，5.5 7.0に比 へ阻止帯の長さは長いが, 輪かくが不明りょらで測定が 目難であった（第 3-a, 3-b, 3-c 表).
第 3-b 表 $\mathrm{pH}$ 值の变量分析結果

\begin{tabular}{|c|c|c|c|c|}
\hline 因 & 変 & 自由 度 & 不偏分散 & 分 散 比 \\
\hline $\mathrm{pH}$ 值 & 23514.5 & 3 & 7838.2 & $23.21 * *$ \\
\hline 誤 差 & 12158.5 & 36 & 337.7 & \\
\hline 全 体 & 35673.0 & 39 & \multicolumn{2}{|l|}{$F_{36}^{3}={ }_{4}^{2}$} \\
\hline
\end{tabular}

第 3-c 表 $\mathrm{pH}$ 值間の有意差の検定

\begin{tabular}{|c|c|c|c|}
\hline $\mathrm{pH}$ & 7.0 & 6.0 & 5.5 \\
\hline 5.0 & $* *$ & $* *$ & \multirow[t]{3}{*}{$* *$} \\
\hline 5.5 & - & \multirow[t]{2}{*}{-} & \\
\hline 6.0 & - & & \\
\hline
\end{tabular}

以上の結果から被検液の $\mathrm{pH}$ 值として, ナイシンの安 定性を考虑し，比較的 $\mathrm{pH}$ の修正が施しやすい 6.0 を採 用することにした。

\section{[実験 4] ナイシン溶媒の検討}

ナイシンは中性からアルカリ性の溶液では溶けにくい が (pH 5.6 で 1,000 $\mu \mathrm{g} / \mathrm{ml}, \mathrm{pH} 4.2$ で12,000 $\mu \mathrm{g} / \mathrm{ml}), \mathrm{pH}$ 2.0 4.0で最も安定といわれている. この意味から通常 ナイシンの溶媒としては $0.02 \mathrm{~N}$ の塩酸溶液が推奖され ているが，本溶媒では定量時における $\mathrm{pH}$ の修正がむず かしく, 操作上不便を感ずる場合が多い.したがって, 本実験では溶媒として $0.02 \mathrm{~N}$ 塩酸溶液を使った場合と， pH 6.0 の Sörensen リン酸緩衝液を使った場合の阻止 帯の長さならびに口紙ろ過による回収率について検討し てみた。

方 法

第 1 図に示すように隇菌蒸留水 (pH 6.0) で 10,000 u/ $\mathrm{ml}$ 濃度のナイシン原液を調製し,これを $0.02 \mathrm{~N}$ 塩酸溶 液と Sörensen リン酸緩衝液でそれぞれ $100 \mathrm{u} / \mathrm{ml}$ 濃度 にまで10倍希釈し, 最終 $\mathrm{pH}$ を6.0に修正してナイシン の定量を行なった。なお，定量試験に当たって被検液を 2 区に分け，一方はそのまま他方はろ液（東洋口紙 No. 2) を使用した.

結 果

要因分析の結果, 非乃過, 乃過とも溶媒の相違による 有意差はなかったが，非ろ過とろ過については両者間に 有意差があることがわかった。 そこで， $0.02 \mathrm{~N}$ 塩酸溶 液のみで調製しろ過しないもの，pH 修正後ろ過したも の扰よ゙ろ過後 $\mathrm{pH}$ を修正したものについて因子間の差 を検定してみると，それぞれの間に有意差が認められ た.すなわち，溶媒の違いは阻止帯の長さにほとんど影 響を及ぼさないが，口紙によるろ過は回収率を著しく低 下させ，またろ過前に $\mathrm{pH}$ を修正したものは，ろ過後 $\mathrm{pH}$ を修正したものに比べ回収率がよかった（第 4-a，4-b， 4-c, 4-d, 4-e 表). 


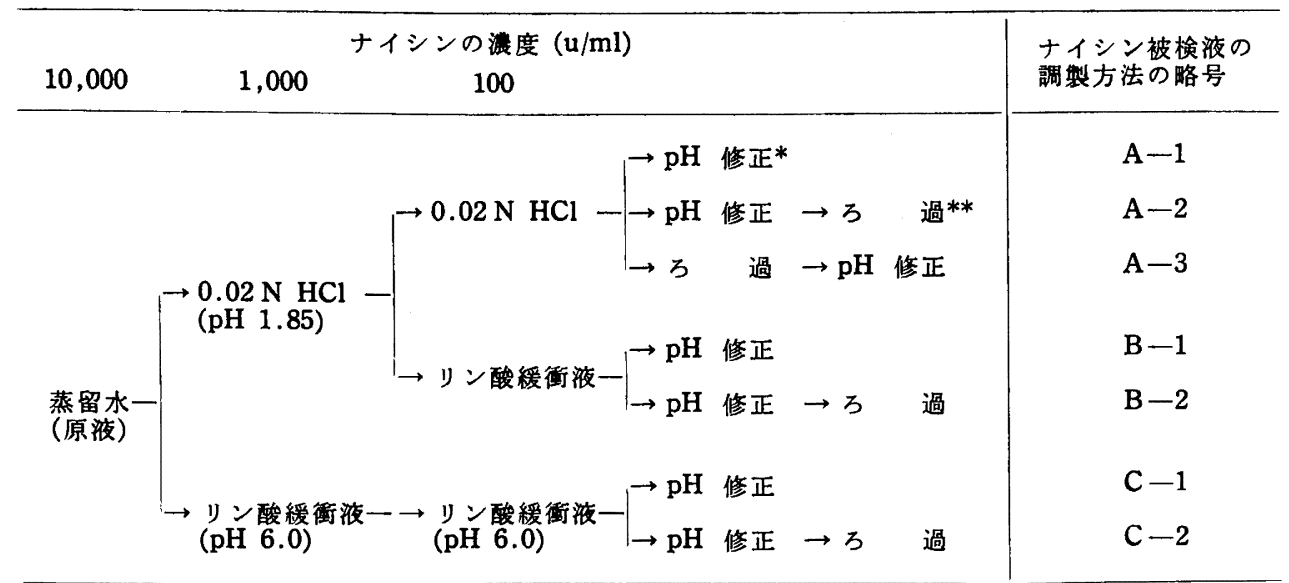

$* \mathrm{pH}$ は 6.0 に修正

**東洋口紙製 No. 2 でろ過

第 1 图ナイシン被検液の調彆法

第 4-a 表 ナイシン被検液の調製方法が阻止帯の長さに 及ぼす影鄂

ナイシン被検液の調製方法

\begin{tabular}{l|r|r|r|r|r|r} 
A-1 & A-2 & A-3 & B-1 & B-2 & C-1 & C-2 \\
\cline { 1 - 4 } $750 *$ & 566 & 587 & 719 & 534 & 720 & 526 \\
762 & 539 & 625 & 708 & 584 & 807 & 545 \\
743 & 561 & 614 & 760 & 560 & 775 & 536 \\
685 & 557 & 534 & 734 & 536 & 749 & 557 \\
691 & 571 & 562 & 772 & 590 & 761 & 558 \\
732 & 523 & 625 & 747 & 499 & 718 & 490 \\
682 & 560 & 636 & 734 & 572 & 733 & 548 \\
741 & 506 & 622 & 748 & 597 & 740 & 521 \\
742 & 484 & 529 & 741 & 558 & 779 & 532 \\
741 & 558 & 643 & 774 & 595 & 763 & 514 \\
* 単位は $1 / 100 \mathrm{~mm}$ & &
\end{tabular}

第 4-b 表 非乃過区の溶媒の要因分析結果

\begin{tabular}{|c|c|c|c|c|}
\hline 要 & 動 & 自 由 度 & 不偏分散 & 分 散 比 \\
\hline 希 䣋 液 & 3868.8 & 2 & 1934.4 & 2.76 \\
\hline 誤 & 18947.5 & 27 & 701.8 & \\
\hline 全体 & 22816.3 & 29 & \multicolumn{2}{|c|}{$F_{27}^{2}=\begin{array}{l}3.35 \cdots * \\
5.49 \cdots * *\end{array}$} \\
\hline
\end{tabular}

第 4-c 表 ろ過区の溶媒の要因分析

\begin{tabular}{|c|c|c|c|c|c|}
\hline 要 & 因 & 動 & 自 由 度 & 不偏分散 & 分 散 比 \\
\hline 希 䣋 & 液 & 4613.6 & 2 & 2306.8 & \multirow[t]{3}{*}{3.01} \\
\hline 誤 & 差 & 20721.1 & 27 & \multirow[t]{2}{*}{767.5} & \\
\hline 全 & 体 & 25334.7 & 29 & & \\
\hline
\end{tabular}

第 4-d 表 万過区・非ろ過区間の要因分析結果

\begin{tabular}{|c|c|c|c|c|c|}
\hline 要 & 因 & 動 & 自由度 & 不偏分散 & 分 散 比 \\
\hline ろ & 過 & 179143.5 & 2 & 89571.7 & \multirow[t]{3}{*}{$77.07 * *$} \\
\hline 誤 & 差 & 31379.5 & 27 & \multirow[t]{2}{*}{1162.2} & \\
\hline 全 & 体 & 210523.0 & 29 & & \\
\hline
\end{tabular}

第 4-e 表 ろ過・非ろ過区間の有意差の検定

\begin{tabular}{c|c|cc} 
万過法 & 非 万 過 & $\mathrm{pH}$ & 修正後ろ過 \\
\hline 万過後 $\mathrm{pH}$ 修正 & $* *$ & $* *$ \\
\hline $\mathrm{pH}$ 修正後乃過 & $* *$ & &
\end{tabular}

[実験 5] 放是条件の検討

検定用培地に試料を重層し，これを $55^{\circ}$ に培盖するま での放置条件とナイシンの回収率の関係をみるために下

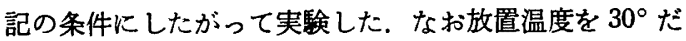
けにしたのは検定菌の発育に影響せずかつ夏季に調節可 能な温度だからである。

条 件

ナイシン液： $100 \mathrm{u} / \mathrm{ml}$ のナイシンを含む $\mathrm{pH} 6.0$ の Sörensen リン酸緩衝液

胞子濃度: $2.4 \times 10^{6} / \mathrm{ml}$

放置温度: $30^{\circ}$

放置時間: $30,60,90,120,150$ 分

放置方法：30 に所定時間放置したのち，一方はその ま $55^{\circ}$ に培養し(常法区)，他方は放固後ナイシン液を 取り除き，すばやく隇菌水を表面に流して洗い，代りに 滅菌流動パラフィンを重層し55に培養した。

結 果

一元配盾法による変量分析の結果, 常法区に扣いて放 
第 5-a 表 検定用培地に被検液を重層したのちの放置時間が阻止帯の長さに及ぼす影響

放 置 時 閒 (分)

\begin{tabular}{c|c|c|c|c}
30 & 60 & 90 & 120 & 150 \\
\hline $531 *(486)$ & $525(534)$ & $552(569)$ & $553(552)$ & $564(543)$ \\
$549(476)$ & $529(517)$ & $528(541)$ & $532(558)$ & $554(579)$ \\
$552(497)$ & $523(557)$ & $552(553)$ & $556(552)$ & $584(610)$ \\
$548(508)$ & $556(509)$ & $516(578)$ & $588(546)$ & $590(578)$ \\
$559(458)$ & $549(525)$ & $559(523)$ & $531(559)$ & $573(573)$ \\
$546(489)$ & $564(485)$ & $533(519)$ & $562(583)$ & $581(520)$ \\
$515(484)$ & $530(526)$ & $555(554)$ & $558(555)$ & $548(595)$ \\
$550(467)$ & $559(516)$ & $563(519)$ & $580(570)$ & $580(559)$ \\
$535(459)$ & $562(521)$ & $524(552)$ & $581(534)$ & $564(533)$ \\
$524(468)$ & $519(529)$ & $555(548)$ & $557(555)$ & $566(603)$
\end{tabular}

（）はパラフィンを重層したときの阻止寡の長さ

* 単位は $1 / 100 \mathrm{~mm}$

第 5-b 表 放置時閒の変量分析結果

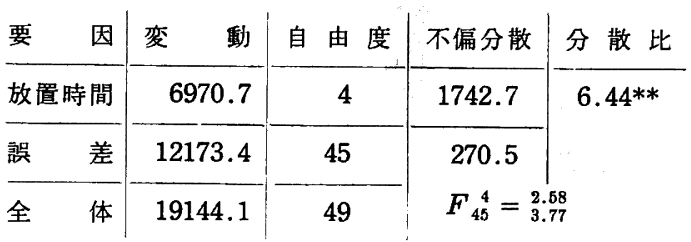

第 5-c 表 放置時間間の有意差の検定

\begin{tabular}{|c|c|c|c|c|}
\hline 放置時間 & 150 分 & 120 分 & 90 分 & 60 分 \\
\hline 30 分 & * * & - & - & \multirow[t]{4}{*}{-} \\
\hline 60 分 & $* *$ & - & \multirow[t]{3}{*}{-} & \\
\hline 90 分 & $* *$ & \multirow[t]{2}{*}{-} & & \\
\hline 120 分 & - & & & \\
\hline
\end{tabular}

第 5-d 表 流動パラフィンを重層するものとの間の有意 差の検定

\begin{tabular}{|c|c|c|c|c|}
\hline 放置時間 & 30 分 & 60 分 & 90 分 120 分 & 150 分 \\
\hline$F_{0}$ & $1228.03^{* *}$ & $106.035^{*}$ & 3.50 & 0.2585 \\
\hline
\end{tabular}

置時間の違いによる影響が認められたので，各時間ごと の有意差を検定した結果30分と 150 分，60分と150分， 90 分と150分の間に有意差が認められた。

つぎにナイシン液を重層してそのまま培養する常法区 と流動パラフィンを代りに重層する方法については30分 と60分放置区で両者間に有意差が認められた。すなわ ち，30分や60分の放置区ではナイシン液を取り除き流動 パラフィンを重層したものに比ベナイシン液を重層した
まま培養した方が回収率が高かった。

以上の結果から，放置条件としては他の時間との間に 有意差が認められず，かつ年間を通じて気温にほとんど 左右されない $30^{\circ}, 120$ 分を採用することとした.

\section{摘 要}

かん詰食品中のナイシンの微生物学的定量法として垂 直拡散法について検討した結果, つぎのごとき定量手順 を確立した。

1. 検定用培地として普通寒天培地（肉エキス $0.5 \%$, ポリペプトン $1.0 \%, \mathrm{NaCl} 0.5 \%$, 寒天 $1.5 \%, \mathrm{pH}$ 7.0)を使用し, $9 \mathrm{ml}$ ずつ中試験管に分注, $121^{\circ}, 15$ 分間高圧隇菌する。

2. 検定用培地を加温溶解し，あらかじめ調製した $B$. stearothermophilus IAM 1035 の胞子懸濁液 $(6 \times$ $\left.10^{6} \sim 6 \times 10^{5} / \mathrm{ml}\right) 1 \mathrm{ml}$ を加之, 十分擤拌したのち $5 \phi$

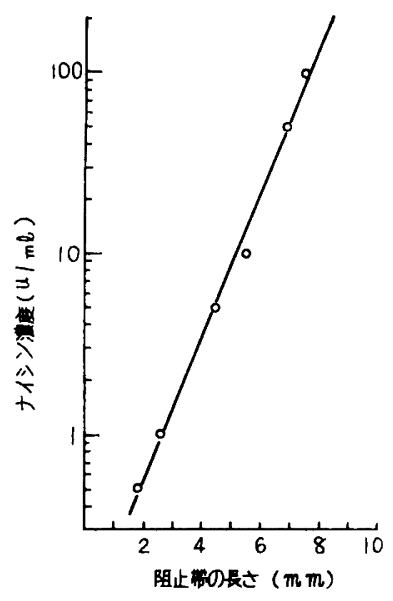

第 2 図ナイシンの標準曲線 
$\times 75 \mathrm{~mm}$ の滅菌小試験管にすばやく分注し（約 0.7 $\mathrm{ml})$, 冷水中で高層にかためる.

3. 高層にかためた検定用培地上にあらかじめ $\mathrm{pH}$ を 6.0に修正した試料約 $0.3 \mathrm{ml}$ を重層し， $30^{\circ}, 120$ 分間 放置したのち, $55^{\circ}, 18 \sim 24$ 時間培養する.

4. 培養終了後形成された阻止帯の長さを透影機にか け，20倍の倍率で $0.01 \mathrm{~mm}$ まで読みとる.

5. 読みとった測定値（10本の平均値）から標準曲線を 利用して未知濃度を算出する.

なお，以上の手順にしたがって pH 6.0 の Sörensen

リン酸緩衝液を用いて求めたナイシンの標準曲線を第 2
図に示した。

終わりに本研究に当たってナイシンの提供をいただい た日本オルガノ商会に深謝する.

文

获

1) N. Snell et al.: J. Appl. Microbiol. 4, 13 (1956).

2) Friedmann, C. Epstein: J. Gen. Microbiol. 5, 830 (1951).

3) C.R. Stumbo et al.: J. Food Sci. 29, 6 (1964).

4) J. Tramer, G. G. Fowlar: J. Sci. Food Agric. 15, 8 (1964). 